\title{
Rancang Bangun Mesin Pemipil Jagung Dua Silinder Menggunakan Motor Listrik
}

\author{
Ali Sai’in ${ }^{1}{ }^{*}$, Eko Saputra ${ }^{2}$, Muhammad Showi Nailul Ulum ${ }^{3}$, Rudino Tuqo Hardian ${ }^{4}$, Wahyu Isti Nugroho ${ }^{5}$ \\ ${ }^{1,2,3,4}$ Teknik Mesin, Jurusan Teknik Mesin, Politeknik Negeri Semarang \\ Jl. Prof. Soedarto, Tembalang, Kec. Tembalang, Kota Semarang, Jawa Tengah 50275 \\ ${ }^{4}$ Teknik Mesin Produksi dan Perawatan, Jurusan Teknik Mesin, Politeknik Negeri Semarang \\ Jl. Prof. Soedarto, Tembalang, Kec. Tembalang, Kota Semarang, Jawa Tengah 50275 \\ *E-mail: ali.saiin@polines.ac.id
}

Diterima: 21 Oktober 2021; Direvisi: 20 Desember 2021; Dipublikasi: 30 Desember 2021

\begin{abstract}
Abstrak
Melihat situasi kebutuhan pakan ternak yang cenderung mengalami peningkatan setiap tahun harus diiringi dengan pengadaan mesin produksi untuk menekan angka produktivitas jagung. Mesin pemipil jagung merupakan suatu alat yang berfungsi untuk melepaskan biji jagung dari tongkolnya. Seiring dengan perkembangan teknologi yang terus mengalami kemajuan banyak sekali mesin produksi bermunculan seperti alat pemipil jagung mulai dari yang dioperasikan secara manual hingga otomatis. Masing-masing mesin mempunyai keunggulan dan kelemahan yang berbeda-beda. Pada perancangan mesin pemipil jagung ini penggerak utamanya menggunakan motor listrik. Perancangan mesin pemipil jagung ini bertujuan untuk membantu meringankan beban petani jagung khusunya. Pada awalnya pemipilan jagung dilakukan dengan tenaga manual, kemudian berkembang menggunakan mesin selep besar namun biaya yang dikeluarkan relatif mahal. Perancangan mesin pemipil jagung dua silinder menggunakan motor listrik untuk mengetahui design serta kontruksi mesin pemipil jagung tepat guna. Pada mesin ini tidak ada batasan diameter jagung untuk proses pemipilan dengan kata lain mesin ini dirancang untuk semua ukuran jagung. Pada perancangan ini menggunakan beberapa tahapan yaitu pertama merencanakan desain kerangka mesin, motor listrik, rasio pulley dan vbelt serta perhitungan poros. Hasil perancangan berupa desain mesin yaitu panjang $1200 \mathrm{~mm}$, lebar $1200 \mathrm{~mm}$ dan tinggi $800 \mathrm{~mm}$. Mesin pemipil digerakan emnggunakan motor listrik daya 500 watt, Rpm 1400 dengan sistem transmisi menggunakan pulley dan $v$-belt rasio $1: 1$. Tidak ada batasan diameter biji jagung pada proses pemipilan menggunakan mesin ini. Sehingga dapat disimpulkan bahwa mesin ini memiliki desain yang tepat guna dan hasil pemipilan yang cukup, mampu mengurangi pengeluaran biaya paska panen petani jagung.
\end{abstract}

Kata Kunci : Mesin Pemipil Jagung; Motor Listrik; Dua silinder

\section{Abstract}

Seeing the situation of animal feed demand that tends to increase every year must be accompanied by the procurement of production machinery to reduce corn productivity. A corn picking machine is a tool that works to release corn kernels from the cob. Along with the development of technology that continues to progress, many production machines are emerging such as corn pickers, from those that are operated manually to automatically. Each machine has different advantages and disadvantages. In the design of this corn grinding machine, the main driver uses an electric motor. The design of this corn picking machine aims to help ease the burden of corn farmers in particular. Initially, the corn milling was done with manual labor, then developed using a large selep machine but the cost is relatively expensive. The design of a two -cylinder corn threshing machine uses an electric motor to determine the design and construction of a suitable corn threshing machine. In this machine there is no limit to the diameter of corn for the plucking process in other words this machine is designed for all sizes of corn. In this design uses several stages, namely the first to plan the design of the engine frame, electric motor, pulley ratio and v-belt and shaft calculation. The design result in the form of machine design is $1200 \mathrm{~mm}$ long, $1200 \mathrm{~mm}$ wide and $800 \mathrm{~mm}$ high. The plucking machine is driven by a 500 watt electric motor, $1400 \mathrm{Rpm}$ with a transmission system using a pulley and v-belt ratio of 1: 1 . There is no limit to the diameter of corn kernels in the plucking process using this machine. So it can be concluded that this machine has a proper design and sufficient plucking results, able to reduce the cost of post-harvest corn farmers.
\end{abstract}

Keyword : Corn Sheller Machine; Electric motor; Two cylinders

\section{Pendahuluan}

Jagung adalah komoditi strategis bagi Indonesia karena mempunyai dimensi penggunaan yang luas seperti pakan ternak (langsung atau olahan), pangan pokok bagi sebagian penduduk (berpotensi untuk masyarakat yang lebih luas dan 
Ali Sai'in dkk /Jurnal Rekayasa Mesin p-ISSN: 1411-6863, e-ISSN: 2540-7678

Vol.16|No.3|391-400|Desember|2021

jajanan, bahan baku industry (pati, gula, pangan olahan), dan energi (bioethanol) [1]. Jagung yang diproduksi menjadi pakan ternak akan melewati beberapa tahapan produksi. Proses paling mendasar yaitu pemipilan jagung. Mesin pemipil jagung berfungsi untuk melepaskan biji jagung dari tongkolnya. Sebelum adanya mesin pemipil ini pemisahan biji jagung dilakukan secara manual menggunakan tenaga manusia yakni dengan tangan. Pada saat ini terdapat berbagai metode untuk pemisahan jagung, yaitu pemisahan secara manual menggunakan tangan dan pemisahan alat bantu sepeti mesin. Pemisahan dengan menggunakan alat bantu mesin diharapkan dapat membantu meningkatkan produktifitas. Beberapa penelitian menunjukkan bahwa penggunaan sistem otomasi/ semi otomasi pada industri mampu meningkatkan produktivitas dan kualitas kerja [2-5]. Setiap jenis alat pemipil jagung memiliki kelebihan dan kekurangan dalam proses produksinya, berdasarkan hasil penelitian terdahulu dengan judul "Rancang Bangun Mesin Pemipil Jagung Skala Industri Rumah Tangga”. Pada rancangan mesin ini masih terdapat kekurangan seperti, hasil pemipilan tidak merata, biji jagung tidak terlepas secara keseluruhan karena diameter biji jagung yang beragam, proses pemipilan akan maksimal pada diameter biji jagung tertentu, masih terdapat biji jagung yang menempel pada bonggolnya sehingga proses pemipilan harus dilakukan secara berulang serta tidak terdapat corong wadah sehingga hasil pemipilan biji jagung tersebar dilantai [6]. Penelitian terdahulu menunjukkan adanya keberhasilan dalam merancang dan memodifikasi mesin pemipil jagung, penelitian ini menunjukkan hasil pipilan terbaik terdapat pada pemipil dengan 4 gerigi $[7,8]$.

Oleh karena itu dibutuhkan perancangan mesin pemipil jagung untuk dapat meningkatkan produktifitas pemipilan jagung dengan kualitas baik dan biaya yang murah. Pada perancangan ini bertujuan untuk melakukan inovasi desain mesin pemipil jagung sebagai solusi dan alternatif mesin pemipil jagung. Pembaruan pada desain ini yaitu pemipil mengunakan dua kepala pemipil dan corong agar biji jagung tidak berserakan. Pemipilan biji jagung dilakukan dengan cara menggesekan bonggol jagung ke kepala pemipil. Mesin mampu memipil biji jagung segala ukuran sehingga tidak terdapat sisa biji jagung yang masih menempel, kemudian mesin ini tidak merusak biji jagung serta hasil pemipilan bersih dan tidak tercampur dengan bonggolnya. Mesin ini dapat mempermudah kerja petani, menghemat waktu dan biaya produksi serta mengasilkan biji jagung yang berkualitas.

\section{Material dan Metodologi}

1. Dasar Pemilihan Bahan

Sebelum pembelian bahan terlebih dahulu dilakukan pemilihan bahan. Dalam pemilihan bahan-bahan tersebut harus mempunyai beberapa kriteria antara lain :

1. Sesuai dengan kegunaanya

2. Mudah diperoleh

3. Efisiensi (ditinjau dari pengerjaan, pengamanan, tenaga untuk pengolahan material, biaya pengoperasian serta perawatanya)

4. Bahan relatif murah

2. Fungsi dari komponen dan Penggunaanya

Fungsi dari komponen dan penggunaannya ditunjukkan pada Tabel 1.

Tabel 1. Komponen mesin pemipil jagung dan penggunaannya

\begin{tabular}{lll}
\hline No & \multicolumn{1}{c}{ Komponen } & \multicolumn{1}{c}{ Penggunaan } \\
\hline 1 & Motor listrik & Motor Listrik merupakan komponen utama dalam mesin pemipil \\
& & jagung sebagai penggerak utama mesin. \\
\hline
\end{tabular}


Ali Sai'in dkk /Jurnal Rekayasa Mesin

p-ISSN: 1411-6863, e-ISSN: 2540-7678

Vol.16|No.3|391-400|Desember|2021

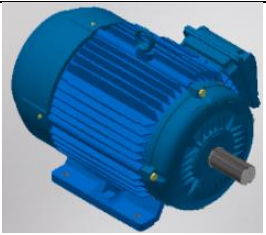

Gambar 1. Motor Listrik

$2 \quad$ Pulley dan belt

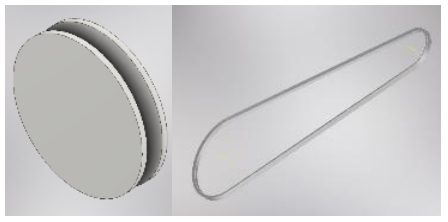

Gambar 2. Pulley dan Belt

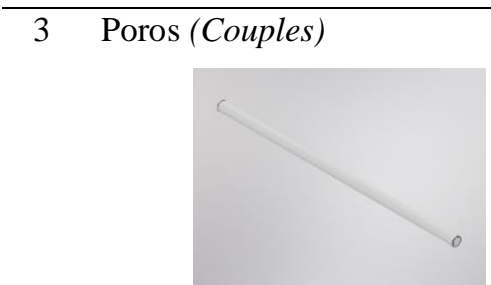

Gambar 3. Poros
Pulley dan Belt berfungsi sebagai penghubung untuk mentransmisikan daya putaran dari mesin ke poros kepala pemipil (head of selector)
4 Head of Selector/ kepala pemipil

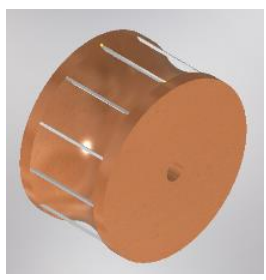

Gambar 4. Head of selector

Head of selector berfungsi untuk memipil jagung / memisahkan biji jagung dari bonggolnya melalui putaran poros diteruskan dari motor, bahan kayu dan besi

5 Bearing/ Bantalan

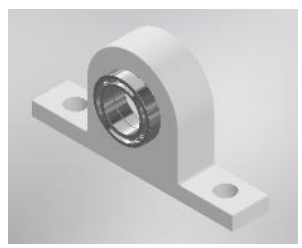

Gambar 5. Bearing

Poros merupakan elemen mesin berbentuk silinder pejal berfungsi untuk mengantarkan putaran yang dihasilkan motor. Poros yang ada di mesin pemipil jagung dipasang horisontal dengan kepala pemipil berada di kedua ujungnya

\section{Frame/ rangka mesin}

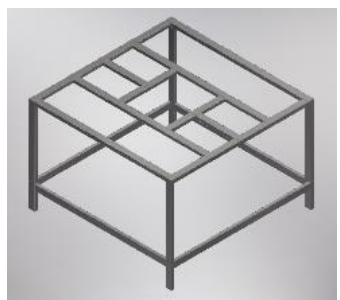

Gambar 6. Rangka
Bearing merupakan komponen yang dapat menerima beban radial murni, beban aksial murni atau gabungan keduanya, bearing juga merupakan penumpu poros yang diberikan beban. Komponen yang digunakan untuk mesin ini yaitu bearing standart. Bearing mempunyai empat bagian utama yaitu cincin luar, cincin dalam, elemen peluru, rol atau pemisah

Rangka berfungsi untuk menahan berat komponen sehingga mesin bisa bekerja dengan maksimal, bahan dari rectangular hollow RHS502525

$7 \quad$ Funnel Container/ Corong Head of selector berfungsi untuk menampung dan meneruskan biji jagung yang sudah terpisah dari bonggol ke dalam wadah, bahan 
Ali Sai' in dkk /Jurnal Rekayasa Mesin

p-ISSN: 1411-6863, e-ISSN: 2540-7678

Vol.16|No.3|391-400|Desember|2021

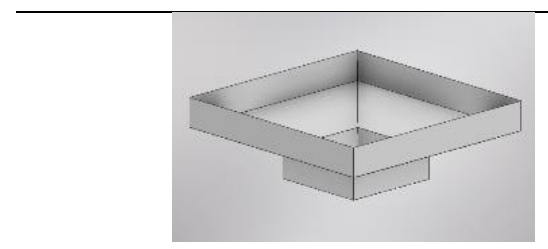

plate ST37 tebal $3 \mathrm{~mm}$

Gambar 7. Head of selector

8 Table Surface

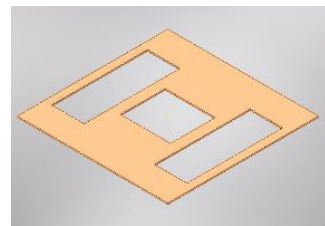

Gambar 8. Table surface

Table surface berfungsi untuk menahan berat kamponen di atasnya, bahan terbuat dari kayu tebal $10 \mathrm{~mm}$

\section{Metodologi}

Adapun metodologi perancangan dapat dilihat pada Gambar 9. Diagram Alir proses perancangan mesin. Perancangan mesin pemipil jagung mengikuti diagram alir seperti yang disajikan pada Gambar 9. dimulai dari study literatur kemudian menentukan konsep perancangan, tahap selanjutnya membuat desain rancangan (skeleton), melakukan perhitungan design calculation seperti, menghitung putaran mesin, daya, sabuk dan pulley, perancanaan poros dan kepala pemipil [9,10]. Hasil dari perancangan ini berupa desain dan mesin pemipil jagung dua silinder dan spesifikasi mesin dan karakterisitik motor listrik yang dibutuhkan oleh mesin. Hasil perancangan ini juga dapat dimanfaatkan untuk meningkatkan produktifitas petani jagung $[11,12]$.

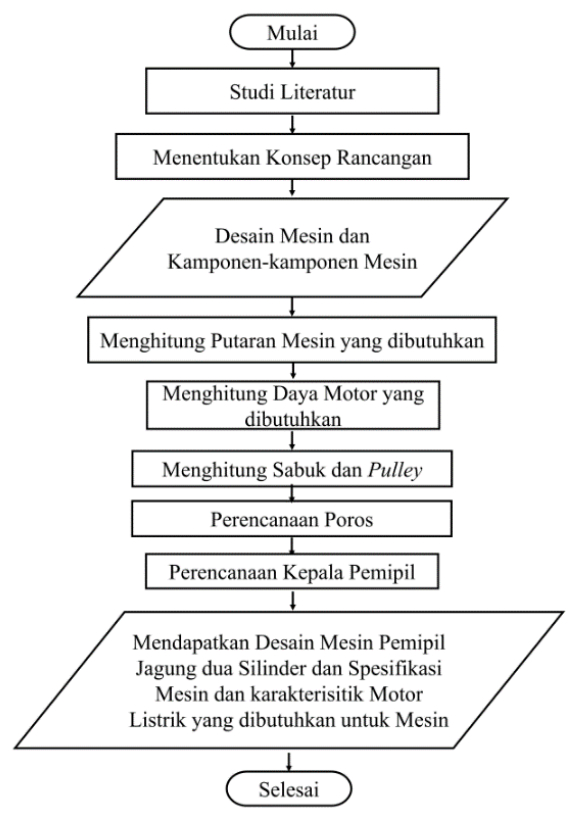

Gambar 9. Diagram alir proses perancangan mesin 
Ali Sai'in dkk /Jurnal Rekayasa Mesin p-ISSN: 1411-6863, e-ISSN: 2540-7678

Vol.16|No.3|391-400|Desember|2021

\section{Hasil dan Pembahasan}

Penelitian tentang rancang bangun mesin pemipil jagung telah dilakukan oleh beberapa peneliti [14,15], sedangkan Gambar 10. Merupakan hasil Rancang bangun mesin pemipil jagung dua silinder menggunakan motor listrik.
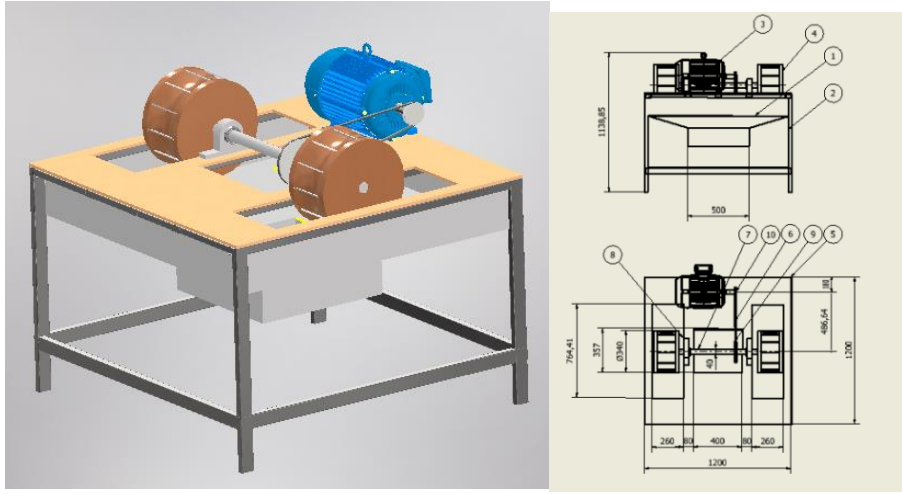

Gambar 10. Skeleton Mesin Pemipil Jagung

Tabel 2. Design Condition

\begin{tabular}{llll}
\hline $\begin{array}{l}\text { Funnel Container } \\
\text { Frame (Rectangular Hollow) }\end{array}$ & Plate ST37 & Thicknes $3 \mathrm{~mm}$ & $500 \times 500 \mathrm{~mm}$ (mulut corong) \\
$\begin{array}{l}\text { Electric Motor } \\
\text { Head of Selector }\end{array}$ & $50 \times 25 \times 2.5 \mathrm{~mm}$ & $1200 \times 1200 \times 800 \mathrm{~mm}$ \\
Table Surface & Wood & $1400 \mathrm{Rpm}$ (Planing) & \\
Belt & Wood & $\boldsymbol{\rho}=\mathbf{1} \mathbf{k g} / \mathbf{m}^{\mathbf{3}}$ & $\mathrm{D}=340 \mathrm{~mm}$ \\
Couples & Rubber & $\boldsymbol{\rho}=\mathbf{1} \mathbf{k g} / \mathbf{m}^{\mathbf{3}}$ & $1200 \times 1200 \mathrm{~mm}$ \\
Bearing & ST37 & $\boldsymbol{\sigma}=37 \mathrm{~kg} / \mathrm{mm}^{2}$ & \\
Pulley Besar $(D p)$ & Standart & & \\
Pulley Motor $(d p)$ & Alumunium & $\boldsymbol{\rho}=\mathbf{2 7 0 0} \mathbf{k g} / \mathbf{m}^{\mathbf{3}}$ & $\mathrm{C}=486,64 \mathrm{~mm}$
\end{tabular}

Tabel 3. Data Sheet Perancangan

\begin{tabular}{ll}
\hline Putaran poros (N) & $1400 \mathrm{Rpm}$ \\
Tegangan tarik makasimum & $\boldsymbol{\sigma}=37 \mathrm{~kg} / \mathrm{mm}^{2}$ \\
Angka keamanan & sf $1=6,0, \mathrm{sf} 2=(1,3-3,0)$ \\
Jarak dp ke Dp (C) & $486.64 \mathrm{~mm}$ \\
Putaran pulley 1 (N1) & $1400 \mathrm{Rpm}$ \\
Putaran pulley 2(N2) & $1400 \mathrm{Rpm}$ \\
Diameter pulley kecil (dp) & $55,8 \mathrm{~mm}$
\end{tabular}

Dalam melakukan perancangan alat pemipil jagung kita harus mengetahui terlebih dahulu ukuran jagung rata-rata. Ukuran jagung hasil panen petani rata-rata antara $\varnothing 40 \mathrm{~mm}$ hingga $\varnothing 65 \mathrm{~mm}$, Panjang jagung $100-220 \mathrm{~mm}$ dan kandungan airnya $15 \%$ - 20\%.

\subsection{Gaya yang dibutuhkan untuk melepaskan biji jagung}


Ali Sai'in dkk /Jurnal Rekayasa Mesin p-ISSN: 1411-6863, e-ISSN: 2540-7678

Vol.16|No.3|391-400|Desember|2021

Dalam perancangan ini untuk menentukan gaya yang dibutuhkan untuk melepaskan 1 butir jagung, menggunakan data hasil penelitian Indra Surya [13], yang dijadikan sebagai parameter kebutuhan gaya pemipil. Gaya untuk memipil satu butir jagung berdasarkan Table 3 sebesar 1,211 N.

Berikut ini adalah hasil pengujian perhitungan biji jagung sebagai berikut :

Tabel 4. Pegujian biji jagung untuk menghitung gaya yang dibutuhkan untuk pemipilan biji jagung

\begin{tabular}{|c|c|c|c|c|c|c|c|}
\hline \multirow[t]{2}{*}{ Pengujian } & \multicolumn{3}{|c|}{ Bahan Uji (Jagung) } & \multicolumn{4}{|c|}{ Hasil Pengujian } \\
\hline & $\begin{array}{c}\text { Jml Biji/ } \\
\text { baris }\end{array}$ & $\begin{array}{c}\text { Jml } \\
\text { Baris/Tongkol }\end{array}$ & Jml Biji/ Tongkol & $\begin{array}{c}\text { Berat } \\
\text { (gr) }\end{array}$ & $\begin{array}{c}\text { Diameter } \\
\text { (mm) }\end{array}$ & $\begin{array}{l}\text { Tebal } \\
(\mathbf{m m})\end{array}$ & $\begin{array}{c}\text { Gaya } \\
(\mathrm{N})\end{array}$ \\
\hline $\mathbf{1}$ & 37 & 16 & 592 & 0.5 & 8 & 4.3 & 1.230 \\
\hline 2 & 38 & 18 & 684 & 0.4 & 7 & 6 & 1.059 \\
\hline 3 & 42 & 18 & 756 & 0.5 & 6 & 4.2 & 1.250 \\
\hline 4 & 41 & 16 & 656 & 0.6 & 9 & 5 & 1.230 \\
\hline 5 & C & 12 & 300 & 0.4 & 8.3 & 4.5 & 1.056 \\
\hline 6 & 29 & 12 & 348 & 0.5 & 8.2 & 4.4 & 1.285 \\
\hline 7 & 43 & 14 & 602 & 0.6 & 9 & 4.2 & 1.375 \\
\hline 8 & 31 & 14 & 432 & 0.6 & 9.5 & 4.4 & 1.085 \\
\hline 9 & 35 & 18 & 630 & 0.4 & 9.3 & 4.7 & 1.210 \\
\hline 10 & 37 & 16 & 592 & 0.5 & 8.7 & 4.3 & 1.330 \\
\hline Rata-rata & 35.8 & 15.4 & 559.2 & 0.5 & 8.4 & 5.46 & 1.211 \\
\hline
\end{tabular}

\subsection{Menghitung kebutuhan putaran mesin pemipil jagung}

Rata-rata baris jangung pertongkol nya 15,4 baris dan jumlah rata-rata biji jagung pertongkol nya 559,2 biji.

Dimana :

a. Banyak biji jagung pertongkol 559,2 x 1,211 N =677, $1914 \mathrm{~N}$

b. Putaran yang dibutuhkan sebesar $1400 \mathrm{rpm}$. Jadi, daya P yang dibutuhkan

$$
\mathrm{T}=\mathrm{F} \times \mathrm{r}=677,1914 \mathrm{~N} \times 0,005 \mathrm{~m}=3,3859 \mathrm{Nm}
$$

$$
\mathrm{P}=\mathrm{T} \mathrm{x} \omega=3,3859 \mathrm{Nm} \times \frac{2 \times 3,14 \mathrm{x} 1400 \mathrm{Rpm}}{60}=496.14 \mathrm{~W}
$$

$$
\begin{aligned}
& \mathrm{P}_{\text {Tot }}=\mathrm{P}_{\text {Pemipil }} \\
& \mathrm{P}_{\text {Tot }}=0,665 \mathrm{HP}
\end{aligned}
$$

Dimana :

$\mathrm{T}=$ Torsi N.m

$\mathrm{P} \quad=$ Daya mesin $\mathrm{HP}$

$\omega \quad=$ Kecepatan

Berdasarkan hasil perhitungan diperoleh spesifikasi motor yang dibutuhkan Sebagai berikut 
Ali Sai' in dkk /Jurnal Rekayasa Mesin p-ISSN: 1411-6863, e-ISSN: 2540-7678

Vol.16|No.3|391-400|Desember|2021

Tabel 5. Spesifikasi motor listrik

\begin{tabular}{|l|l|l|}
\hline & \multicolumn{2}{|c|}{ Spesifikasi Product } \\
\hline Merk & Shimizu \\
\hline Code & PO865 \\
\hline & Type & SGJS 500 \\
\hline & Category & Semijet Stainless \\
\hline & Berat & $23 \mathrm{~kg}$ \\
\hline$f c$ & 8.5 \\
\hline
\end{tabular}

\subsection{Menghitung kebutuhan daya motor}

a. Gaya total yang digerakan poros

Diketahui :

M1 = Masa pully $0,5 \mathrm{~kg}$

M2 = Masa poros 4,5 $\mathrm{kg}$

$\mathrm{M}$ tot $=\mathrm{M} 1+\mathrm{M} 2$

$\operatorname{Tr}=(\mathrm{M}$ tot $.9,81 \mathrm{~m} / \mathrm{s})$

F adalah gaya potong untuk satu biji jagung $1.211 \mathrm{~N}$

Ftot $=$ F.jml besi pemipil $+\left(\right.$ Mtot $\left.\left..9,81 \mathrm{~m} / \mathrm{s}^{2}\right)=1,211 \mathrm{~N}+\left((0,5 \mathrm{~kg}+4,5 \mathrm{~kg}) \cdot 9,81 \frac{\mathrm{m}}{\mathrm{s}^{2}}\right)\right)$

$F t o t=50,261 N$ gaya yang bekerja pada pemipil untuk jagung

b. Kecepatan linear $(\mathrm{V})$

$$
\begin{gathered}
\mathrm{V}=\frac{\pi \cdot \mathrm{d} \cdot \mathrm{N}}{60}=\frac{3,14 \cdot 55,8 \mathrm{~mm} \cdot 1400 \mathrm{Rpm}}{60}=4.088,28 \frac{\mathrm{mm}}{\mathrm{s}^{2}}=4,08846 \mathrm{~m} / \mathrm{s}^{2} \\
W=F \text { tot } x v=50,261 \times 4,08846=205,49 \mathrm{Watt}==0,27 \mathrm{HP}
\end{gathered}
$$

Dimana:

$$
\begin{aligned}
& \mathrm{W}=\text { Daya potong yang dibutuhkan }(\mathrm{Hp}) \\
& \mathrm{F} \text { tot } \\
& =\text { Gaya total }(\mathrm{N}) \\
& \mathrm{v} \quad=\text { kecepatan linear }(\mathrm{m} / \mathrm{s})
\end{aligned}
$$

\subsection{Perancangan Pulley dan Belt}

V-belt merupakan salah satu jenis transmisi penghubung berbahan dasar karet dan mempunyai penampang trapesium.Dalam pengaplikasianya V-belt dibelitkan mengelilingi alur pulley. Bagian belt yang membelit pulley akan mengalami lengkungan sehigga lebar bagian dalamnya akan bertambah besar (Sularso dan Kiyokatsu Suga, 1991:163). 
Ali Sai' in dkk /Jurnal Rekayasa Mesin p-ISSN: 1411-6863, e-ISSN: 2540-7678

Vol.16|No.3|391-400|Desember|2021

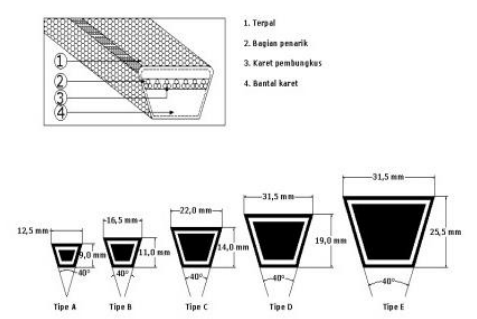

Gambar 11. Kontruksi dan ukuran penampung sabuk

a. Menghitung rasio pulley

Diketahui :

Putaran motor $=1400 \mathrm{rpm}$

Putaran pulley besar yang direncanakan $(\mathrm{Dp})=1400 \mathrm{rpm}$

Diameter pulley penggerak $(\mathrm{dp})=55,8 \mathrm{~mm}$

$\frac{\mathbf{n} 1}{\mathbf{n} 2}=\frac{\mathrm{Dp}}{\mathbf{d p}}($ Sularso hal.166)

$$
\begin{aligned}
& \frac{1400}{1400}=\frac{D p}{55,8} \\
& D p=\frac{1400 \times 55,8}{1400}=55,8 \mathrm{~mm}
\end{aligned}
$$

Berdasarkan perhitunga diperoleh rasio pulley $1: 1$

b. Menghitung panjang belt (L)

Dimana :

$\mathrm{Dp}=$ Ukuran pulley penggerak $(55,8 \mathrm{~mm})$

$\mathrm{dp}=$ Ukuran pulley digerakkan $(55,8 \mathrm{~mm})$

$4 \mathrm{C}=$ Jarak antar pulley yang direncanakan $(486,64 \mathrm{~mm})$

$L=2 C+\frac{\pi}{2}(d p+D p)+\frac{1}{4 . C}(D p-d p) 2 \quad$ (Sularso, $\left.1991: 170\right)$

$L=2.486,64+\frac{3,14}{2}(55,8+55,8)+\frac{1}{4486,64}(55,8-55,8)^{2}$

$L=973,28+174,74=1148,021 \mathrm{~mm}$

c. Menghitung jarak sumbu poros yang sebenarnya (C2)

$\mathrm{b}=2 \mathrm{~L}-\pi(\mathrm{Dp}+\mathrm{dp})=(2 \times 1.148,021)-(3,14(55,8+55,8)=2296,042-350,424$

$\mathrm{b}=1945,618 \mathrm{~mm}$

$\mathrm{C} 2=\frac{\mathrm{b} \pm \sqrt{\mathrm{b}^{2}}-8 \llbracket(\mathrm{Dp}-\mathrm{dp})^{\wedge} 2}{8}$

$\mathrm{C} 2=\frac{1945,618 \pm \sqrt{1945,618^{2}}-8(\mathrm{Dp}-\mathrm{dp})^{\wedge} 2}{8}=\frac{1945,618 \pm \sqrt{3785429.40}-0}{8}$

$\mathrm{C} 2=\frac{1945,618+1945,618}{8}=486,4 \mathrm{~mm}$

\subsection{Perancangan Poros}

Poros pada umumnya meneruskan daya melalui sabuk, roda gigi, dan rantai. Dengan demikian poros tersebut mendapat beban putir dan lentur sehingga pada permukaan akan terjadi tegangan geser karena momen puntir dan tegangan karena momen lentur. Diameter poros ditentukan dengan mengikuti persamaan-persamaan sebagai berikut : 
Ali Sai' in dkk /Jurnal Rekayasa Mesin p-ISSN: 1411-6863, e-ISSN: 2540-7678

Vol.16|No.3|391-400|Desember|2021

a. Menentukan momen puntir (T)

$T=9,74.10^{5} \frac{P d}{n 1} \quad$ (Sularso, 1978;7)

$T=9,74.10^{5} \frac{496,14 \mathrm{watt}}{1400 \mathrm{rpm}}=345171,6 \mathrm{~kg} \cdot \mathrm{mm}=34517,16 \mathrm{~N} \cdot \mathrm{mm}$

dimana :

$\mathrm{T}=$ Momen Puntir

Pd = Daya Motor $1=$ Putaran Mesin

b. Tegangan Geser $(\tau \mathrm{g})$

$\tau g=\frac{\sigma}{S f 1 \times s f 2} \quad$ (Sularso, 1978;8)

$\tau g=\frac{37 \mathrm{~kg} / \mathrm{mm}^{2}}{6,0 \times 3,0}=18,5 \mathrm{~N} / \mathrm{mm}^{2}$

dimana :

$\tau \mathrm{g}=$ tegangan geser yang diizinkan $\left(\mathrm{kg} / \mathrm{mm}^{2}\right)$

$\sigma \mathrm{b}=$ Kekuatan tarik bahan (bahan yang diambil St37 mempunyai $\sigma \mathrm{b}: 37 \mathrm{~kg} / \mathrm{mm}^{2}$ )

Sf1 = faktor keamanan : 6,0 (karena menggunakan bahan S-C)

Sf2 = faktor keamanan 1,3 - 3,0 (karena alur pasak, poros bertingkat dan pengaruh kekasaran permukaan)

c. Menentukan Diameter Poros mesin pemipil

Menggunakan rumus:

$d s=\left[\frac{5.1}{\tau a}(\right.$ K.C.T) $] 1 / 3($ Sularso, $2004: 4)$

$d s=\left[\frac{5 \cdot 1}{18,5}(2,3 \cdot 1,8 \cdot 34517,16)\right]^{1 / 3}$

$d s=39394,1^{1 / 3}$

$d s=34,02 \mathrm{~mm}$

$\mathrm{ds}=$ diameter poros $(\mathrm{mm})$

$\tau \mathrm{a}=$ tegangan izin bahan $\left(\mathrm{kg} / \mathrm{mm}^{2}\right)$

$\mathrm{Cb}=$ Faktor koreksi akibat beban lentur $(1,2-2,3)$

$\mathrm{Kt}=$ Faktor koreksi momen puntir $(1.5-3)$

$\mathrm{T}=$ Momen puntir (kg.mm)

\section{Kesimpulan}

Mesin Pemipil jagung merupakan alat yang digerakan oleh motor listrik untuk memudahkan petani dalam proses pemisahan biji jagung dari bonggolnya. Desain mesin pemipil jagung sebelumnya masih meninggalkan sisa biji jagung yang belum terlepas dari bonggolnya, biji jagung yang sudah terpipil masih berserakan di lantai, sehingga proses pemipilan harus dilakukan secara berulang untuk mendapatkan hasil maksimal. Setelah dilakukan inovasi desain mesin pemipil jagung dua kepala silinder dapat melakukan pemipilan semua diameter biji jagung. Biji jagung yang sudah terlepas bisa langsung diarahkan kewadah melalui corong yang berada di bawah kepala pemipil, dan hasil pemipilan lebih bersih serta tidak menyisakan biji jagung pada bonggolnya. Proses pemipilan terjadi karena gesekan antara kepala pemipil dengan biji jagung. Dari perancangan mesin pemipil jagung ini digerakan oleh motor daya 486,14 watt dengan 
Ali Sai'in dkk /Jurnal Rekayasa Mesin p-ISSN: 1411-6863, e-ISSN: 2540-7678

Vol.16|No.3|391-400|Desember|2021

putaran poros silinder mesin $1400 \mathrm{rpm}$ ditranmisikan dengan pulley V-belt. Gaya untuk melepaskan biji jagung per tongkolnya sebesar 3,3859 N. Mesin pemipil jagung berukuran 1200 x 1200 x $800 \mathrm{~mm}$.

\section{Daftar Pustaka}

[1] Tajuddin Bantacut, Muammar Tawaruddin Akbar, Yasser Raden Firdaus. Pengembangan Jagung untuk Ketahanan Pangan Industri dan Ekonomi. 2015; 24 (2): p. 135-148.

[2] Kokkonen, T. The Impact of Automation and Robotization on Income Distribution in Post Industrial Countries: Who are The Winners and What Step Should Society Take?. Finlandia: Aalto University Schol of Business. 2016; p. $38-40$.

[3] Chaudari, Niraj C. Patii, Pavitra D., Chaudari, Mayur R., Lanje, Pankaj K., dan More, Mayur S. Increasing Productivity and Quality of Product by Implementations of Automation in Manufacturing Sectors. International Journal of Advance Research, Ideas and Innovations in Technology. 2017; 3 (2): p. 9-12.

[4] Vermeulen, B., Kesselhut, J., Pyka, A. dan Saviotti, P.P. The Impact of Automation on Employment: Just The Usual Structural Change. Sustainability MDPI. 2018; 10 (1661): p. 1-27.

[5] Sima, V., Gheorge, I.G., Subic, J. dan Nancu, D. Influences of The Industry 4.0 Revolution on The Human Capital Deveopment and Customer Behavior: A Systematic Review. Sustainability MDPI. 2020: 12 (4035): p. 1-28.

[6] Tri Agus Susanto, Dermawan. Rancang Bangun Mesin Pemipil Jagung Skala Industri Rumah Tangga. 2017; ISBN. 978-602-60766-3-2: p. 18-24.

[7] Nurdin Ar Rasid, Budianto Lanya, Tamrin. Modifikasi Alat Pemipil Jagung Semi Mekanis. Jurnal Teknik Pertanian Lampung. 2014; Vol 3 No 2: p. 163-172.

[8] Bustami. Rancang Bangun Mesin Pemipil Jagung Metode Pipa Berigi. Tugas Akhir. 2016; Politeknik Negeri Padang.

[9] Harahap, G. 2000. Perencanaan Teknik Mesin Edisi Keempat Jilid 1 (Shigley, J.E., dan Mitchell, L.D. Terjemahan) Jakarta: Erlangga.

[10] Sularso, dan Kiyokatsu Suga. 1997. Dasar Perencanaan dan Pemilihan Elemen Mesin. Jakarta: Pradnya Paramita.

[11] Mastuki, Harjo Saputro. Meningkatkan Produktifitas Petani Jagung dengan Inovasi Alat Pemipil Jagung Sederhana. Jurnal Abdi Karya. 2018. Vol 1. No.2; p. 175-177

[12] Nurmeji, Nurmeji, et al. "Rancang Bangun Alat Pemipil Jagung Sederhana." Agroteknika, vol. 2, no. 1, 30 Jun. 2019, pp. 11-19

[13] Indra Surya, Tri Pujianto. Perancangan Alat Pemipil Jagung. Jurnal Teknik Mesin UBL. 2018. Vol 5. No.2; p. 1926

[14] Mustapa, R., Djafar, R., \& Botutihe, S. (2020). RANCANG BANGUN DAN UJI KINERJA MESIN PEMIPIL JAGUNG MINI TYPE SYLINDER. Jurnal Teknologi Pertanian Gorontalo (JTPG), 5(1), 9-16.

[15] Hamka Amrin, Jamaludin P, Lahming. (2019). Rancang Bangun Alat Pemipil Jagung Semi Mekanis. Jurnal Pendidikan Teknologi Pertanian, 5(2), 25-30. 